\title{
Coding sequence analysis of GNRHR and GPR 54 in patients with congenital and adult-onset forms of hypogonadotropic hypogonadism
}

Felecia Cerrato, Jenna Shagoury, Milena Kralickova, Andrew Dwyer, John Falardeau, Metin Ozata ${ }^{1}$, Guy Van Vliet ${ }^{2}$, Pierre Bouloux ${ }^{3}$, Janet E Hall, Frances J Hayes, Nelly Pitteloud, Kathryn A Martin, Corrine Welt and Stephanie B Seminara

Reproductive Endocrine Unit, Massachusetts General Hospital BHX 504, Fruit Street, Boston, Massachusetts 02114, USA, ${ }^{1}$ Department of Endocrinology, GATA Haydarpasa Training Hospital, Kadlkoy, Istanbul, Turkey, ${ }^{2}$ Department of Pediatrics, University of Montreal, Montreal, Canada and ${ }^{3}$ Department of Endocrinology, Royal Free Hospital, London, UK

(Correspondence should be addressed to S B Seminara; Email: sseminara@partners.org)

\begin{abstract}
Objective: To determine the frequency of rare nucleotide variants in GNRHR and GPR54 in a large cohort of probands $(n=166)$ with normosmic idiopathic hypogonadotropic hypogonadism $(\mathrm{nIHH})$, characterized by mode of inheritance, testicular volume, and presence or absence of endogenous LH pulsations.

Methods: Whenever possible, probands answered detailed questionnaires, underwent full physical exams, and underwent q 10-min frequent blood sampling for LH. Exons segments for GNRHR and GPR 54 were screened for mutations. Nucleotide changes were identified as rare variants if they occurred at less than $1 \%$ frequency in an ethnically matched control population.

Results: Sixty-two percent of male probands were classified as sporadic, meaning that no other family members had delayed puberty or nIHH. In contrast, $61 \%$ of female probands were from familial pedigrees, with either autosomal dominant or autosomal recessive inheritance. Patients displayed a broad spectrum of disease severity based on testicular size and endogenous LH pulsations. Twenty-four rare variants were identified in GNRHR (within 15 probands) and seven rare variants in GPR54 (within five probands).

Conclusions: Rare variants in GNRHR are more common than GPR54 in a nIHH population.
\end{abstract}

European Journal of Endocrinology 155 S3-S10

\section{Introduction}

While the traditional definition of idiopathic hypogonadotropic hypogonadism is the absence of spontaneous sexual maturation in the setting of low gonadotropins and sex steroids, the past 10 years have been witness to a greater appreciation of the phenotypic richness of this disorder, with nuances in the patterns of sexual development (1-3), the presence or absence of luteinizing hormone (LH) pulsations $(4,5)$, and associated anomalies (6-8). The past decade has also given rise to several new genes that have been implicated in idiopathic hypogonadotropic hypogonadism $(\mathrm{IHH})$, including genes which play a role in the gonadotropin-releasing hormone $(\mathrm{GnRH})$ neuronal migration, such as $\operatorname{KAL1}(9,10)$, genes modulating

This paper was presented at the 4th Ferring Pharmaceuticals International Paediatric Endocrinology Symposium, Paris (2006). Ferring Pharmaceuticals has supported the publication of these proceedings.
GnRH release, such as GPR54 $(11,12)$, and finally, genes which affect the responsiveness of the gonadotropes at the level of the pituitary gland such as GNRHR (13). Therefore, the ability to make genotype-phenotype correlations for this disorder is challenged by the ability to correlate subtleties in phenotype with the evergrowing complexities of gene/protein function. Rather than focus on one proband and the gene/protein structure-function relationships pertinent to his/her individual mutations, this paper attempts to identify the number of rare base pair variants in two genes (GNRHR and GPR54) in a large cohort of patients with normosmic IHH (nIHH).

\section{Materials and methods}

All studies were reviewed and approved by the Partners Healthcare Institutional Review Board (IRB) and study subjects provided written informed consent prior to participation. 


\section{Diagnosis}

Participants in the study were either referred directly to the Reproductive Endocrine Associates of Massachusetts General Hospital (MGH) for clinical evaluation or were referred directly by their physicians to participate in our genetic studies. The diagnosis of IHH was made based on the failure to undergo complete spontaneous pubertal development by 18 years of age with low serum sex steroid levels (testosterone $\leq 3.4 \mathrm{nmol} / \mathrm{l}$, estradiol $\leq 73 \mathrm{pmol} / \mathrm{l}$ ) and inappropriately low or normal gonadotropin levels. Additional evidence for a diagnosis of IHH was provided by (i) the absence of LH secretion during 12-24 h of q 10-min blood sampling; (ii) normal imaging of the hypothalamicpituitary region; and (iii) otherwise normal anterior pituitary function. Whenever possible, patients were interviewed by both a clinical investigator and a genetics counselor using an IRB-approved questionnaire, so that a full family pedigree could be obtained.

Whenever possible, olfactory testing was performed using the University of Pennsylvania smell identification test. Only normosmic probands were included in this cohort. If a proband's family members were determined to have isolated anosmia or Kallman syndrome (IHH and anosmia/hyposmia), the proband was excluded from the present cohort.

Patients were classified based on their testicular size before the initiation of exogenous gonadotropin or pulsatile GnRH therapy. Determination of testicular volume was made by Prader orchidometer or measurements of length $\times$ width, which were then converted into cubic centimeters using Hansen and With's formula: $0.52 \times$ longitudinal axis $\times$ square of transverse axis (14). Patients were categorized as having adultonset IHH if they had undergone a normal timing and onset of puberty (and proven paternity in some cases), but subsequently developed isolated hypogonadotropic hypogonadism without an identifiable cause (1).

\section{Ethnicity}

The majority of patients were Caucasian and from a mixed European background; six individuals were Hispanic; four were Asian, and three were African American. Thirty-eight individuals were from Turkey. Pedigree analysis was performed to ascribe the likely mode of disease transmission as outlined in previous studies $(5,15)$. Modes of inheritance included autosomal dominant, autosomal recessive, X-linked (male probands only), unknown (two brothers affected in a single sibship, male probands only), sporadic (no affected family members), and no pedigree information. Probands were classified into the last category if they (i) were adopted, (ii) lost to followup, or (iii) had not yet responded to requests to discuss the family history by detailed questionnaire. Only probands whose family members had either IHH or delayed puberty were included in the familial categories.

\section{Clinical studies}

Patients seen at the MGH were admitted to the General Clinical Research Center for a neuroendocrine evaluation including a q 10-min blood sampling study (12-24 h) to assess endogenous LH secretion. LH pulsatility was determined using a modification of the Santen and Bardin method (16).

\section{Clinical assays}

Blood-sampling studies were performed over a 25-year period; therefore, two different immunoassay systems were used for the measurements of LH. Originally, LH measurements were made via RIA with a limit of detection of $0.8 \mathrm{IU} / \mathrm{l}$ (17). Later, this assay was switched to an automated microparticle enzyme immunoassay (MEIA) (AxSYM System; Abbott Laboratories) with a limit of detection of $1.6 \mathrm{IU} / \mathrm{l}$. The MEIA was calibrated using the same RPs as the RIA to make results comparable across data sets. The data regarding the presence or absence of LH pulses are based on the respective limits of detection of each system.

\section{Mutation analysis}

Genomic DNA was extracted from peripheral blood leukocytes of cultured white blood cells. Forty-eight probands were screened for GNRHR using the technique of temperature-gradient gel electrophoresis (5). The remaining probands were screened by PCR amplification of exon segments and direct sequencing. For GPR 54, all screening was performed by direct sequencing (12). Because the primers for each exon were placed approximately a few hundred base pairs on either side of the intron-exon junction, small segments of noncoding DNA were also analyzed. Nucleotide changes were cataloged as rare variants if they occurred at less than $1 \%$ frequency in ethnically matched control populations.

Although the goal of the mutation analysis was to catalog coding sequence variation in GNRHR and GPR 54 in all referred nIHH probands, in a few instances, limited DNA quantity precluded the study of both genes. These individuals were excluded from the data analysis. In one proband, exon 1 of GPR 54 amplified poorly and further sequencing will be required. Some probands have been previously reported (GNRHR: $n=48$; GPR 54: $n=63)(5,12)$.

\section{Control populations}

For GNRHR, control DNA was derived from blood samples either from anonymous MGH Blood Bank volunteers $(n=50)$ or from prospectively recruited volunteers determined to have normal reproductive function by history and physical examination $(n=96$ Caucasian). For GPR54, DNA derived from several 
sources was used to compare frequencies of base pair changes: (i) blood bank volunteers $(n=50)$; (ii) prospectively recruited healthy volunteers $(n=45$ Caucasian, 45 Hispanic); (iii) phenotypically normal parents of children with a mucolipodosis type IV $(n=36$ Ashkenazi Jewish); and (iv) immortalized cell lines purchased from Coriell Laboratories $(n=50$ African American, $n=50$ Middle Eastern). The most recent patient demographics regarding admissions to $\mathrm{MGH}$ indicate that $74 \%$ are Caucasian, $3 \%$ African American, 3\% Hispanic, $0.1 \%$ Native American, 1\% Asian, 1\% other, and $18 \%$ unknown. Therefore, the majority of the blood bank donors would be expected to be Caucasian of mixed European descent and the MGH blood bank donors and the Caucasian group were combined as a single group for determination of polymorphism frequencies in Caucasian controls.

\section{Results}

\section{Modes of inheritance}

The cohort comprised 138 male and 28 female probands. For the female probands, $61 \%$ of pedigrees met the criteria for either autosomal dominant or recessive inheritance (Fig. 1). In contrast, male probands were predominantly sporadic, with only $10 \%$ attributed to dominant or recessive inheritance. Even if male probands from families classified as 'unknown' (i.e. brother-brother combination) were attributed to recessive inheritance, the proportion of dominant and recessive cases relative to the total would account for a much smaller proportion compared with female cases. Despite the difference in the absolute numbers of male versus female probands, the proportion of cases in which no pedigree information was available was approximately equal, $20 \%$ for the females and $22 \%$ for the males,

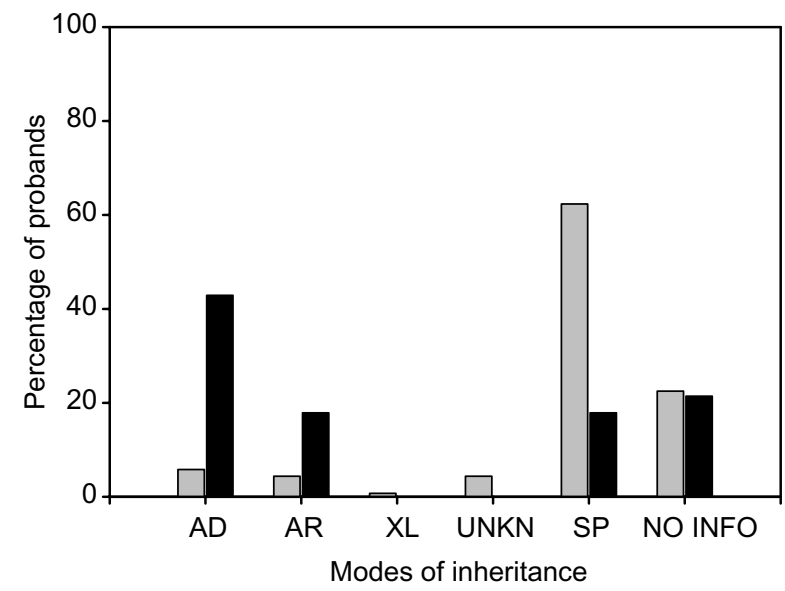

Figure 1 Breakdown of modes of inheritance of patient cohort $A D$, autosomal dominant; AR, autosomal recessive; XL, X-linked; UNKN, unknown; SP, sporadic; NO INFO, no pedigree information. Black bar, females; grey bar, males; $n=166$.
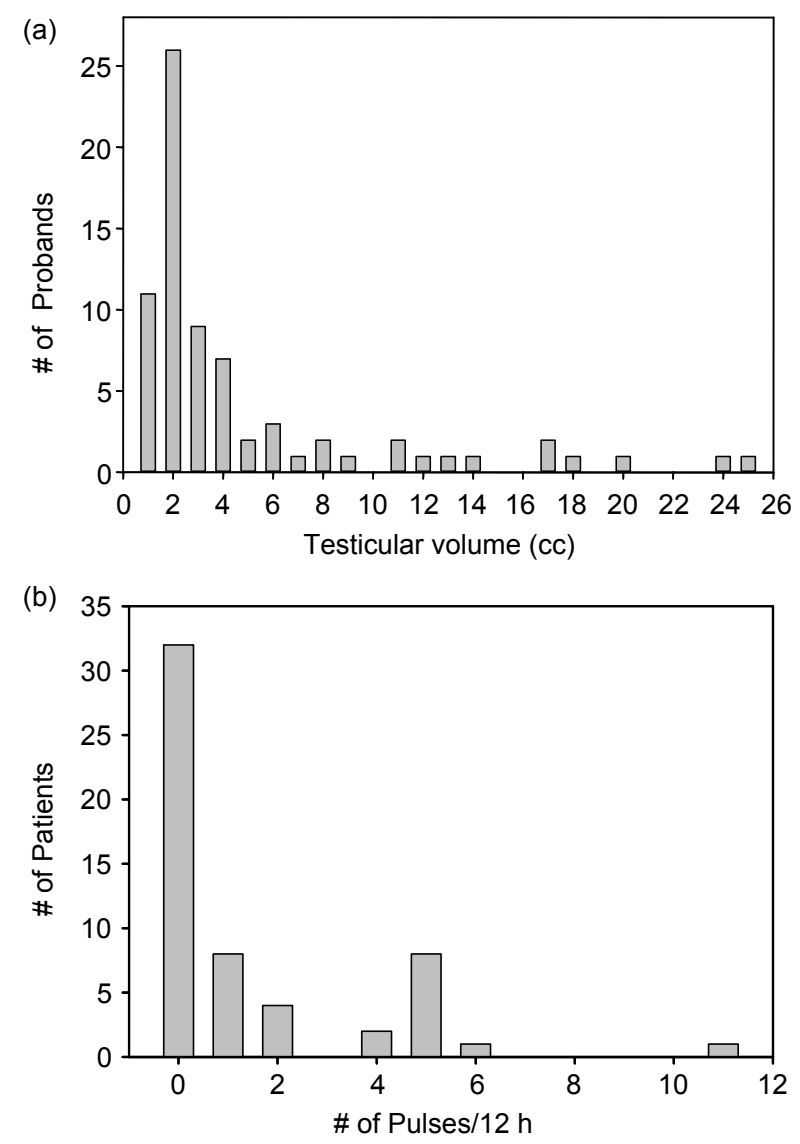

Figure 2 Frequency histogram of (A) testicular volumes $(n=75)$ and $(B)$ endogenous pulsations $(n=56)$.

suggesting that the recruitment and pedigree expansion efforts were not biased toward a particular gender.

\section{Phenotype}

The baseline testicular volume before the initiation of therapy with either exogenous gonadotropins or GnRH was recorded in 75 of the 138 men in this cohort and ranged from prepubertal $\left(\leq 4 \mathrm{~cm}^{3}\right)$ to normal $\left(>15 \mathrm{~cm}^{3}\right)$. However, the majority of men $(53 / 75)$

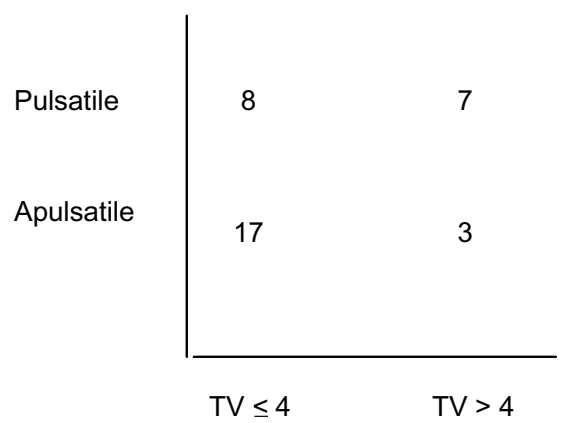

Figure 3 Testicular volume versus endogenous pulsations $(n=35)$. 
had prepubertal-sized testes (Fig. 2A). Blood sampling was performed in 56/138 men. Thirty-two men had no detectable LH pulses in a 12-h interval (Fig. 2B).

Thirty-five males in the cohort had both a confirmed pretreatment testicular volume and blood-sampling data. Patients presenting with a testicular volume of $\leq 4 \mathrm{~cm}^{3}$ were twice as likely to be apulsatile for $\mathrm{LH}$, whereas patients presenting with a testicular volume of $>4 \mathrm{~cm}^{3}$ were twice as likely to have detectable pulsations (Fig. 3).

\section{Rare variants identified}

In GNRHR, 15 probands (eight males and seven females) were identified with rare variants, incorporating compound heterozygous, homozygous, and simple heterozygous changes (total number of variants $=24$, Table 1). Five males had rare variants identified on only one allele (Q106R $(n=2), \mathrm{R} 262 \mathrm{Q}, \mathrm{H} 247 \mathrm{H}$, and F216F). One proband with a Q106R heterozygous change had adult-onset hypogonadotropic hypogonadism $(\mathrm{AOHH})$.

For GPR 54, five probands were identified with rare variants (total number of variants $=7$, Table 1 ). Two variants were also identified in ethnically matched control population at a frequency of $>1 \%$.

\section{Discussion}

The primary goal of this study was to perform mutation analysis for GNRHR and GPR54 in a large cohort of probands with $\mathrm{nIHH}$. In the past decade, several genes have been implicated in the pathophysiology of IHH, establishing distinct physiological pathways. The first gene to be identified was $\operatorname{KAL1}(9,10)$; the protein it encodes, anosmin, plays guidance roles in (i) axonal outgrowth/branching from the olfactory bulb (18) and (ii) the migratory activity of GnRH neurons (19). Anosmin may also act as a co-ligand modulator of fibroblast growth factor receptor 1 (FGFR1) (20), whose parent gene has also been identified as harboring mutations in familial Kallmann syndrome (8). Therefore, these two genes, and possibly others yet to be discovered appear to comprise a key pathway affecting olfactory bulb development and, by extension, GnRH neuronal migration. Similarly, mutations in GPR 54 and GNRHR have also been implicated in IHH - new data suggest that GPR54 acts at the level of the hypothalamus as a key regulator of GnRH secretion (21-29). Therefore, the pathway encompassing metastinGPR54-GnRH-GnRHR appears to modulate GnRH release and pituitary responsiveness in contrast to GnRH neuronal migration, and was the target pathway for the genetic analyses presented in this report. However, the ratio of male:female probands, and the distribution of inheritance patterns bring forth novel observations worthy of discussion on their own merits.
The male:female ratio within the assembled normosmic cohort was almost 5:1, further corroborating the remarkable male: female predominance in hypogonadotropism, as previously reported by our group (15). Although the X-linked gene, KAL1, was the first gene to be associated with Kallmann syndrome (IHH and anosmia), coding sequence changes in KAL1 do not account for the excess of male cases (30). Since the phenotype of anosmia appears to be completely expressed in male mutation carriers (i.e. all males with mutations have a smell defect), our finding of a strong male:female predominance in a normosmic population is all the more striking. In addition, only one male in the assembled cohort appeared to be from an X-linked pedigree using Mendelian principles (but ultimately was found to carry a nucleotide deletion in NROB1, formerly known as DAX1) (31). Although formal segregation analysis was not performed in this study, simple pedigree inspection did not suggest the presence of additional X-linked genes.

The relative proportion of the different inheritance modalities between the male and female probands is also quite striking. The majority of male probands were sporadic, meaning that no other family members had either IHH or delayed puberty. In contrast, the majority of female probands were ascribed to dominant or recessive inheritance. Why such inheritance discrepancies exist is unclear. However, a female proband classified as coming from a pedigree with autosomal recessive inheritance, as determined by our criteria, is more likely to carry a GNRHR variant, as discussed in detail below.

Mutation analysis was performed for both GNRHR and GPR 54 in this report. Variants were identified in both genes. Traditionally, the determination of whether a nucleotide variant is a true mutation is based on (i) the nature of the base pair change, with greater confidence given to frameshifts and premature termination codons; (ii) the presence or absence of the base pair change in an appropriately sized, ethnically matched population; and (iii) function studies of mutant constructs in vitro. If a base pair change was identified in a proband in GNRHR or GPR 54, as well as in an ethnically matched control population at a frequency of $1 \%$ or greater, it was not cataloged in this report as a rare variant, although the determination of polymorphism frequency in a reference population can be adjusted depending on the desired significance (32).

In the genetic analysis, more rare variants were identified in GNRHR $(n=24)$ than GPR54 $(n=7)$. For GNRHR, although the variants encompassed compound heterozygote, homozygote, and simple heterozygote changes, the majority of male probands (5/8) were found to carry rare variants on only one allele, with no coding sequence abnormality identified on the opposing allele. Such variants have been reported both by our group (5), as well as others (33); however, GNRHR has consistently been described as an autosomal recessive 
Table 1 Rare variants in GNRHR and GPR54.

\begin{tabular}{|c|c|c|c|c|c|c|}
\hline & $\begin{array}{l}\text { Dominant } \\
(n=8 \mathrm{M}, 12 \mathrm{~F})\end{array}$ & $\begin{array}{l}\text { Recessive } \\
(n=6 \mathrm{M}, 5 \mathrm{~F})\end{array}$ & $\begin{array}{l}\text { X-linked } \\
(n=1 \mathrm{M})\end{array}$ & $\begin{array}{l}\text { Unknown } \\
(n=6 \mathrm{M})\end{array}$ & $\begin{array}{l}\text { Sporadic } \\
(n=86 \mathrm{M}, 5 \mathrm{~F})\end{array}$ & $\begin{array}{l}\text { No ped info } \\
(n=31 \mathrm{M}, 6 \mathrm{~F})\end{array}$ \\
\hline \multirow[t]{7}{*}{ GNRHR } & $\begin{array}{l}\text { F } 1059001 \\
\text { c. } 987+495 \text { T >C } \\
\text { Non-coding variant } \\
(1 / 192 \text { Caucas chrom, }<1 \%)\end{array}$ & $\begin{array}{l}\text { F } 01411 \\
\text { C.317 A }>\text { G; c.785 G >A } \\
\text { Q106R; R262Q }\end{array}$ & & & $\begin{array}{l}\text { M } 12001 \\
M 53501 \\
\text { C. } 317 A>G \\
\text { Q106R }\end{array}$ & $\begin{array}{l}\text { M } 85501 \\
\text { c. } 648 \mathrm{C}>\mathrm{T} \\
\text { F216F }\end{array}$ \\
\hline & $\begin{array}{l}\text { F } 35901 \\
\text { c.30 T >A; c.31 C>A; c.959 C > T } \\
\text { N10K; Q11K; P320L }\end{array}$ & $\begin{array}{l}F 43502 \\
\text { C.317 A> G; c.797 T>G } \\
\text { Q106R; L266R }\end{array}$ & & & $\begin{array}{l}(1 / 100 \text { anon donor chrom }) \\
(0 / 192 \text { Caucas chrom, }<1 \%) \\
\text { M } 06507\end{array}$ & $\begin{array}{l}\text { F } 98501 \\
\text { c. } 987+495 \mathrm{~T}>\mathrm{C} \\
\text { Non-coding variant } \\
(1 / 192 \text { Caucas chrom, }<1 \%)\end{array}$ \\
\hline & & $\begin{array}{l}\text { F } 78505 \\
\text { C.247 C> G; c.317 A>G } \\
\text { L83V; Q106R }\end{array}$ & & & $\begin{array}{l}\text { C. } 785 \mathrm{G}>\mathrm{A} \\
\mathrm{R} 262 \mathrm{Q}\end{array}$ & \\
\hline & & $\begin{array}{l}\text { F } 78701 \\
\text { C.317 G >A; c.743-132 A > G } \\
\text { Q106R; non-coding variant }\end{array}$ & & & $\begin{array}{l}\text { M } 38601 \\
\text { C. } 741 \mathrm{C}>\mathrm{T} \\
\mathrm{H} 247 \mathrm{H}\end{array}$ & \\
\hline & & & & & $\begin{array}{l}\text { M } 47601 \\
\text { C.317 A > G; c.317 A>G } \\
\text { Q106R; Q106R }\end{array}$ & \\
\hline & & & & & $\begin{array}{l}\text { M } 17701 \\
\text { C. } 95 \text { C > T; c.599 G >A } \\
\text { T32I; C200Y }\end{array}$ & \\
\hline & & & & & $\begin{array}{l}\text { M } 72001 \\
\text { C.286 C > T; c.317 A > G } \\
\text { P96S; Q106R }\end{array}$ & \\
\hline \multirow[t]{3}{*}{ GPR54 } & & $\begin{array}{l}\text { M } 68611 \\
\text { C. } 443 \text { T >C; C. } 443 \text { T >C } \\
\text { L148S; L148S }\end{array}$ & & & $\begin{array}{l}\text { M } 03406 \\
\text { C.991 C > T; c.1195 T >A } \\
\text { R331X; X399R }\end{array}$ & $\begin{array}{l}\text { M } 59401 \\
\text { C. } 1079 \text { A }>\text { T } \\
\text { H360L }\end{array}$ \\
\hline & & & & & $\begin{array}{l}\text { M } 67601 \\
\text { M } 1147001 \\
\text { c. } 505-59 \mathrm{G}>\mathrm{T} \\
\text { Non-coding variant } \\
\text { M } 69301 \\
\text { c. } 1197+122 \mathrm{C}>\mathrm{G} \\
\text { Non-coding variant }\end{array}$ & $\begin{array}{l}\text { M } 1057001 \\
\text { c.9 C }>\text { T } \\
\text { T3T } \\
(1 / 90 \text { Hispanic chrom, }>1 \%)\end{array}$ \\
\hline & & & & & $\begin{array}{l}\text { F } 1145001 \\
\text { C. } 565 \mathrm{G}>\mathrm{A} \\
\text { A189T } \\
(1 / 90 \text { Hispanic chrom, }>1 \%) \\
(1 / 90 \text { Caucas chrom, }>1 \%)\end{array}$ & \\
\hline
\end{tabular}


gene for $\mathrm{IHH}$, requiring the presence of mutations on both alleles to cause disease. As this study examined coding sequence predominantly, it is certainly possible that variants in non-coding sequence (introns or regulatory regions) were missed by the present methods of analysis. However, a growing body of data challenges the traditional description of GNRHR as a 'recessive gene'. In vitro, GNRHR mutations - mutations that were originally identified from patients with $\mathrm{IHH}$ - have frequently been shown to be misrouted, retained in the endoplasmic reticulum, and exerting dominant negative effects on WT receptors (34). If these in vitro observations are true in vivo, it is possible that heterozygote variants in GNRHR could contribute to disease phenotype in the absence of mutations on the opposite allele.

Of the five GNRHR heterozygote changes identified in this study, three were Q106R $(n=2)$, and R262Q, the two most frequently identified base pair changes in $\mathrm{IHH}$ patients $(5,13,35-40)$. Of the two probands carrying Q106R, previously demonstrated to decrease receptor binding (13), one was a patient with $\mathrm{AOHH}$, who presented with a testicular volume well within the normal range. This is the first report of a coding sequence change in an 'IHH gene' in a patient with the adult-onset form of the disorder. As a variant of IHH, $\mathrm{AOHH}$ is a puzzling entity - by definition, these patients have normal puberty and in some cases, paternity, before the development of hypogonadotropism. In contrast to patients with acquired $\mathrm{HH}$ due to an identifiable cause (i.e. mass lesion in the pituitary), these patients have no clear etiology for their reproductive endocrinopathy. As homozygosity for Q106R has been associated with the fertile eunuch variant form of $\mathrm{IHH}$, it is theoretically possible that Q106R in heterozygous form could play a role in other attenuated forms of the disease.

Complicating these phenotypic issues is the observation that the base pair change leading to Q106R was originally identified in an anonymous MGH blood bank donor. Since the possibility that an IHH proband donated blood products cannot be excluded, the frequency of this variant in a larger Caucasian population with normal reproductive function $(n=96$ individuals, 192 chromosomes) was evaluated. Because Q106R was not identified in this larger control population, it does not appear to be a common polymorphism, but what role it plays in causing hypogonadotropism, or what other genes it interacts with, will require further exploration.

The male probands carrying GNRHR variants were examined in light of their phenotypic assessments of disease severity. Testicular size in males can be used as a marker of prior exposure to endogenous $\mathrm{GnRH}$ or gonadotropins (41). Similarly, the presence of spontaneous LH pulsations at baseline has also been interpreted as evidence for an attenuated hypogonadotropic phenotype $(12,38)$. The majority of male probands in this study had prepubertal-sized testes (although testicular volumes spanned the range from $<1$ to $25 \mathrm{~cm}^{3}$ ) and undetectable LH pulses at baseline. Not unexpectedly, small testicular volumes were more likely to be associated with an absence of LH pulses and testicular volumes $>4 \mathrm{~cm}^{3}$ were more likely to be associated with detectable pulsations. However, two male probands (GNRHR: R262Q heterozygote and Q106R/P96S) had prepubertal-sized testes but detectable pulses.

In contrast to male probands, $80 \%$ female probands with autosomal recessive inheritance (4/5), had rare variants in GNRHR. Three of five had rare variants in the coding sequence, one of five had rare variants in both coding and non-coding sequences. Therefore, female probands from pedigrees manifesting autosomal recessive inheritance are more likely to carry sequence variants in GNRHR than males.

In contrast to GNRHR, only seven variants were identified in GPR54. Two probands have been previously reported, and of the three novel variants, two were in non-coding sequence. The remaining variant, H360L, was identified in heterozygous form. No female probands were identified with rare sequence variants.

In summary, a pathway of culprit genes for nIHH is beginning to emerge. Even excluding anosmia and skeletal/mid-line defects, patients with $\mathrm{nIHH}$ display a broad spectrum of disease severity and modes of inheritance. Rare variants are more common in GNRHR than GPR54.

\section{Acknowledgements}

This work was supported by the Mallinckrodt GCRC at Massachusetts General Hospital, grant number M01RR-01 066, National Center for Research Resources, National Institutes for health. Also supported by the Specialized Cooperative Centers Program in Reproduction Research, grant number U54-HD028138-16.

\section{References}

1 Nachtigall LB, Boepple PA, Pralong FP \& Crowley WF Jr. Adultonset idiopathic hypogonadotropic hypogonadism-a treatable form of male infertility. New England Journal of Medicine 1997336 $410-415$.

2 Pitteloud N, Boepple PA, Decruz S, Valkenburgh SB, Crowley WF Jr \& Hayes FJ. The fertile eunuch variant of idiopathic hypogonadotropic hypogonadism: spontaneous reversal associated with a homozygous mutation in the gonadotropin-releasing hormone receptor. Journal of Clinical Endocrinology and Metabolism 200186 2470-2474.

3 Pitteloud N, Hayes FJ, Boepple PA, Decruz S, Seminara SB, MacLaughlin DT \& Crowley WF Jr. The role of prior pubertal development, biochemical markers of testicular maturation, and genetics in elucidating the phenotypic heterogeneity of idiopathic hypogonadotropic hypogonadism. Journal of Clinical Endocrinology and Metabolism 200287 152-160. 
4 Oliveira LMB, Seminara SB, Beranova M, Hayes FJ, Valkenburgh SB, Schipani E, Costa EM, Latronico AC, Crowley WF Jr \& Vallejo M. The importance of autosomal genes in Kallmann syndrome: genotype-phenotype correlations and neuroendocrine characteristics. Journal of Clinical Endocrinology and Metabolism 200186 $1532-1538$.

5 Beranova M, Oliveira LMB, Bedecarrats GY, Schipani E, Vallejo M, Ammini AC, Quintos JB, Hall JE, Martin KA, Hayes FJ, Pitteloud N, Kaiser UB, Crowley WF Jr \& Seminara SB. Prevalence, phenotypic spectrum, and modes of inheritance of GnRH receptor mutations in idiopathic hypogonadotropic hypogonadism. Journal of Clinical Endocrinology and Metabolism 200186 1580-1588.

6 Quinton R, Duke VM, Robertson A, Kirk JMW, Matfin G, de Zoysa PA, Azcona C, MacColl GS, Jacobs HS, Conway GS, Besser M, Stanhope RG \& Bouloux P-MG. Idiopathic gonadotrophin deficiency: genetic questions addressed through phenotypic characterization. Clinical Endocrinology 200155 163-174.

7 Quinton R, Barnett P, Coskeran P \& Bouloux P-MG. Gordon Holmes spinocerebellar ataxia: a gonadotrophin deficiency syndrome resistant to treatment with pulsatile gonadotrophin-releasing hormone. Clinical Endocrinology 199951 525-529.

8 Dode C, Levilliers J, Dupont JM, De Paepe A, Le Du N, SoussiYanicostas N, Coimbra RS, Delmaghani S, Compain-Nouaille S, Baverel F, Pecheux C, Le Tessier D, Cruaud C, Delpech M, Speleman F, Vermeulen S, Amalfitano A, Bachelot Y, Bouchard P, Cabrol S, Carel JC, Delemarre-van de Waal HA, Goulet-Salmon B, Kottler ML, Richard O, Sanchez-Franco F, Saura R, Young J, Petit C \& Hardelin JP. Loss-of-function mutations in FGFR1 cause autosomal dominant Kallmann syndrome. Nature Genetics 2003 $33463-465$.

9 Legouis R, Hardelin JP, Levilliers J, Claverie JM, Compain S, Wunderle V, Millasseau P, Le Paslier D, Cohen D, Caterina D, Bougueleret L, Delemarre-van de Waal HA, Lutfalla G, Weissenbach J \& Petit C. The candidate gene for the X-linked Kallmann syndrome encodes a protein related to adhesion molecules. Cell $199167423-435$.

10 Franco B, Guioli S, Pragliola A, Incerti B, Bardoni B, Tonlorenzi R, Carrozzo R, Maestrini E, Pieretti M, Taillon-Miller P, Brown CJ, Willard HF, Lawrence C, Persico MG, Camerino G \& Ballabio A. A gene deleted in Kallmann's syndrome shares homology with neural cell adhesion and axonal path-finding molecules. Nature 1991353 529-536.

11 de Roux N, Genin E, Carel J-C, Matsuda F, Chaussain J-L \& Milgrom E. Hypogonadotropic hypogonadism due to loss of function of the KiSS1-derived peptide receptor GPR54. PNAS $2003 \mathbf{1 0 0}$ 10972-10976.

12 Seminara SB, Messager SM, Chatzidki EE, Thresher RR, Acierno JS Jr, Shagoury JK, Bo-Abbas Y, Kuohung W, Schwinof K, Hendrick AG, Zahn D, Dixon J, Kaiser UB, Slaugenhaupt SA, Gusella JF, O'Rahilly S, Carlton MBL, Crowley WF Jr, Aparicio SJR \& Colledge WH. The GPR 54 gene as a regulator of puberty. New England Journal of Medicine 2003349 1614-1627.

13 de Roux N, Young J, Misrahi M, Genet R, Chanson P, Schaison G \& Milgrom E. A family with hypogonadotropic hypogonadism and mutations in the gonadotropin-releasing hormone receptor. New England Journal of Medicine 1997337 1597-1602.

14 Hansen PF \& With TK. Clinical measurements of the testes in boys and men. Acta Medica Scandinavica 1952266 457-465.

15 Waldstreicher J, Seminara SB, Jameson JL, Geyer A, Nachtigall LB, Boepple PA, Holmes LB \& Crowley WF Jr. The genetic and clinical heterogeneity of gonadotropin-releasing hormone deficiency in the human. Journal of Clinical Endocrinology and Metabolism 1996 $814388-4395$.

16 Hayes FJ, McNicholl DJ, Schoenfeld D, Marsh EE \& Hall JE. Free alpha-subunit is superior to luteinizing hormone as a marker of gonadotropin-releasing hormone despite desensitization at fast pulse frequencies. Journal of Clinical Endocrinology and Metabolism $1999 \mathbf{8 4} 1028-1036$.
17 Filicori M, Butler JP \& Crowley WF Jr. Neuroendocrine regulation of the corpus luteum in the human. Evidence for pulsatile progesterone secretion. Journal of Clinical Investigation 198473 1638-1647.

18 Bulow HE, Berry KL, Topper LH, Peles E \& Hobert O. Heparan sulfate proteoglycan-dependent induction of axon branching and axon misrouting by the Kallmann syndrome gene kal-1. PNAS $2002996346-6351$.

19 Cariboni A, Pimpinelli F, Colamarino S, Zaninetti R, Piccolella M, Rumio C, Piva F, Rugarli EI \& Maggi R. The product of X-linked Kallmann's syndrome gene (KAL1) affects the migratory activity of gonadotropin-releasing hormone (GnRH)-producing neurons. Human Molecular Genetics 200413 2781-2791.

20 Gonzalez-Martinez D, Kim SH, Hu Y, Guimond S, Schofield J, Winyard P, Vannelli GB, Turnbull J \& Bouloux PM. Anosmin-1 modulates fibroblast growth factor receptor 1 signaling in human gonadotropin-releasing hormone olfactory neuroblasts through a heparan sulfate-dependent mechanism. Journal of Neuroscience 200424 10384-10392.

21 Gottsch ML, Cunningham MJ, Smith JT, Popa SM, Acohido BV, Crowley WF, Clifton DK \& Steiner RA. A role for kisspeptins in the regulation of gonadotropin secretion in the mouse. Endocrinology $20041454073-4077$.

22 Navarro VM, Castellano JM, Fernandez-Fernandez R, Barriero ML, Roa J, Sanchez-Criado JE, Aquilar E, Dieguez C, Pinilla L \& Tena-Sempere M. Developmental and hormonally regulated messenger ribonucleic acid expression of KiSS-1 and its putative receptor, GPR 54, in rat hypothalamus and potent luteinizing hormone-releasing activity of KiSS-1 peptide. Endocrinology 2004 145 4565-4574.

23 Matsui H, Takatsu Y, Kumano S, Matsumoto H \& Ohtaki T. Peripheral administration of metastin induces marked gonadotropin release and ovulation in the rat. Biochemical and Biophysical Research Communications 2004320 383-388.

24 Thompson EL, Patterson M, Murphy KG, Smith KL, Dhillo WS, Todd JF, Ghatei MA \& Bloom SR. Central and peripheral administration of kisspeptin-10 stimulates the hypothalamicpituitary-gonadal axis. Journal of Neuroendocrinology 200416 $850-858$.

25 Irwig MS, Fraley GS, Smith JT, Acohido BV, Popa SM, Cunningham MJ, Gottsch ML, Clifton DK \& Steiner RA. Kisspeptin activation of gonadotropin releasing hormone neurons and regulation of KiSS1 mRNA in the male rat. Neuroendocrinology $200480264-272$.

26 Navarro VM, Ferndandez-Fernandez R, Castellano JM, Roa J, Mayen A, Barreiro ML, Gaytan F, Aguilar E, Pinilla L, Dieguez C \& Tena-Sempere M. Advanced vaginal opening and precocious activation of the reproductive axis by KiSS-1 peptide, the endogenous ligand of GPR54. Journal of Physiology $2004 \mathbf{5 6 1}$ 379-386.

27 Shahab M, Mastronardi C, Seminara SB, Crowley WF, Ojeda SR \& Plant TM. Increased hypothalamic GPR 54 signaling: a potential mechanism for initiation of puberty in primates. PNAS $2005 \mathbf{1 0 2}$ 2129-2134.

28 Messager SM, Chatzidki EE, Ma D, Hendrick AG, Zahn D, Dixon J, Thresher RR, Malinge I, Lomet D, Carlton MBL, Colledge WH, Caraty A \& Aparicio SJR. Kisspeptin directly stimulates gonadotropin-releasing hormone release via $G$ protein-coupled receptor 54. PNAS $20051021761-1766$.

29 Dhillo WS, Chaudhri OB, Patterson M, Thompson EL, Murphy KG, Badman MK, McGowan BM, Amber V, Patel S, Ghatei MA \& Bloom SR. Kisspeptin-54 stimulates the hypothalamic-pituitary gonadal axis in human males. Journal of Clinical Endocrinology and Metabolism 2005 90 6609-6615.

30 Georgopoulos NA, Pralong FP, Seidman CE, Seidman JG, Crowley WF Jr \& Vallejo M. Genetic heterogeneity evidenced by low incidence of KAL-1 gene mutations in sporadic cases of gonadotropin-releasing hormone deficiency. Journal of Clinical Endocrinology and Metabolism 199782 213-217. 
31 Seminara SB, Achermann JC, Genel M, Jameson JL \& Crowley WF Jr. X-linked adrenal hypoplasia congenita: a mutation in DAX1 expands the phenotypic spectrum in males and females. Journal of Clinical Endocrinology and Metabolism $1999 \mathbf{8 4} 4501-4509$.

32 Collins JS \& Schwartz CE. Detecting polymorphisms and mutations in candidate genes-letter to the editor. American Journal of Human Genetics 200271 1251-1252.

33 Lanfranco F, Gromoll J, von Eckardstein S, Herding EM, Nieschlag E \& Simoni M. Role of sequence variations of the $\mathrm{GnRH}$ receptor and $\mathrm{G}$ protein-coupled receptor 54 gene in male idiopathic hypogonadotropic hypogonadism. European Journal of Endocrinology 2005 $153845-852$.

34 Knollmann PE, Janovick JA, Brothers SP \& Conn PM. Parallel regulation of membrane trafficking and dominant-negative effects by misrouted gonadotropin-releasing hormone receptor mutants. Journal of Biological Chemistry $200528024506-24514$.

35 Layman LC, Peak DB, Xie J, Sohn SH, Reindollar RH \& Gray MR. Mutation analysis of the gonadotropin-releasing hormone receptor gene in idiopathic hypogonadotropic hypogonadism. Fertility and Sterility $1997 \mathbf{6 8} 1079-1085$.

36 de Roux N, Young J, Brailly-Tabard S, Misrahi M, Milgrom E \& Schaison G. The same molecular defects of the gonadotropin-releasing hormone receptor determine a variable degree of hypogonadism in affected kindred. Journal of Clinical Endocrinology and Metabolism $199984567-572$.

37 Caron P, Chauvin S, Christin-Maitre S, Bennet A, Lahlou N, Counis R, Bouchard P \& Kottler ML. Resistance of hypogonadic patients with mutated $\mathrm{GnRH}$ receptor genes to pulsatile $\mathrm{GnRH}$ administration. Journal of Clinical Endocrinology and Metabolism 1999 84 990-996.
38 Seminara SB, Beranova M, Oliveira LMB, Martin KA, Crowley WF Jr \& Hall JE. Successful use of pulsatile gonadotropin-releasing hormone $(\mathrm{GnRH})$ for ovulation induction and pregnancy in a patient with $\mathrm{GnRH}$ receptor mutations. Journal of Clinical Endocrinology and Metabolism 200085 556-562.

39 Dewailly D, Boucher A, Decanter C, Lagarde JP, Counis R \& Kottler ML. Spontaneous pregnancy in a patient who was homozygous for the Q106R mutation in the gonadotropin releasing hormone receptor gene. Fertility and Sterility 200277 1288-1291.

40 Kottler ML, Chauvin S, Lahlou N, Harris CE, Johnston CJ, Lagarde JP, Bouchard P, Farid NR \& Counis R. A new compound heterozygous mutation of the gonadotropin-releasing hormone receptor (L314X, Q106R) in a woman with complete hypogonadotropic hypogonadism: chronic estrogen administration amplifies the gonadotropin defect. Journal of Clinical Endocrinology and Metabolism $2000 \mathbf{8 5}$ 3002-3008.

41 Pitteloud N, Hayes FJ, Dwyer AA, Boepple P, Lee H \& Crowley WF Jr. Predictors of outcome of long-term GnRH therapy in men with idiopathic hypogonadotropic hypogonadism. Journal of Clinical Endocrinology Metabolism 200287 4128-4136.

Received 12 May 2006

Accepted 21 June 2006 